\title{
Balaenoptera edeni skull from the Holocene (Quaternary) of Osaka City, Japan
}

\author{
Yoshihiro Tanaka and Hiroyuki Taruno
}

\begin{abstract}
Skull remains of Balaenoptera edeni from the Holocene (about 8800 to 4000 years before present; a transgressive period) of Osaka City, Japan, was previously identified as $B$. acutorostrata. Here, we describe in detail and reidentify it based on having a large alisphenoid, which contacts with the squamosal widely and a broader rostrum than the one of $B$. acutorostrata. The specimen adds a chronologically and geographically new record to the not well-known species. The specimen suggests that the modern distribution of the species probably had already established about 8800 to 4000 years ago, which was the age of the Jomon transgression creating the Kawachi Bay, the former condition of Osaka Plain. More remains of $B$. edeni will provide better resolution of their distributional history.
\end{abstract}

Yoshihiro Tanaka. Osaka Museum of Natural History, Nagai Park 1-23, Higashi-Sumiyoshi-ku, Osaka, 5460034, Japan tanaka@mus-nh.city.osaka.jp and Division of Academic Resources and Specimens, Hokkaido University Museum, Kita 10, Nishi 8, Kita-ku, Sapporo, Hokkaido 060-0810 Japan and Numata Fossil Museum, 2-7-49, 1 Minami, Numata Town, Hokkaido, 078-2202 Japan Hiroyuki Taruno. Osaka Museum of Natural History, Nagai Park 1-23, Higashi-Sumiyoshi-ku, Osaka, 5460034, Japan hiroyukitaruno@gmail.com

Keywords: Bryde's whale; Balaenoptera brydei; Alisphenoid; Balaenoptera acutorostrata; Minke whale; Jomon period

\section{INTRODUCTION}

The Holocene had a transgressive period in Japan. Currently, the Osaka Plain is located east to the Osaka Bay, which is a part of the Seto Inland Sea. Several thousand years before, the Osaka
Plain was dominated by the ocean. Its eastern part was named as the Kawachi Bay (Figure 1).

During 1960s, a series of huge land constructions had made for expansion of subway and highway systems, and also establishing buildings at the Osaka Plain. During that period, some whalebone

Tanaka, Yoshihiro and Taruno, Hiroyuki. 2017. Balaenoptera edeni skull from the Holocene (Quaternary) of Osaka City, Japan. Palaeontologia Electronica 20.3.50A: 1-13, https://doi.org/10.26879/785

palaeo-electronica.org/content/2017/2025-a-japanese-holocene-whale 

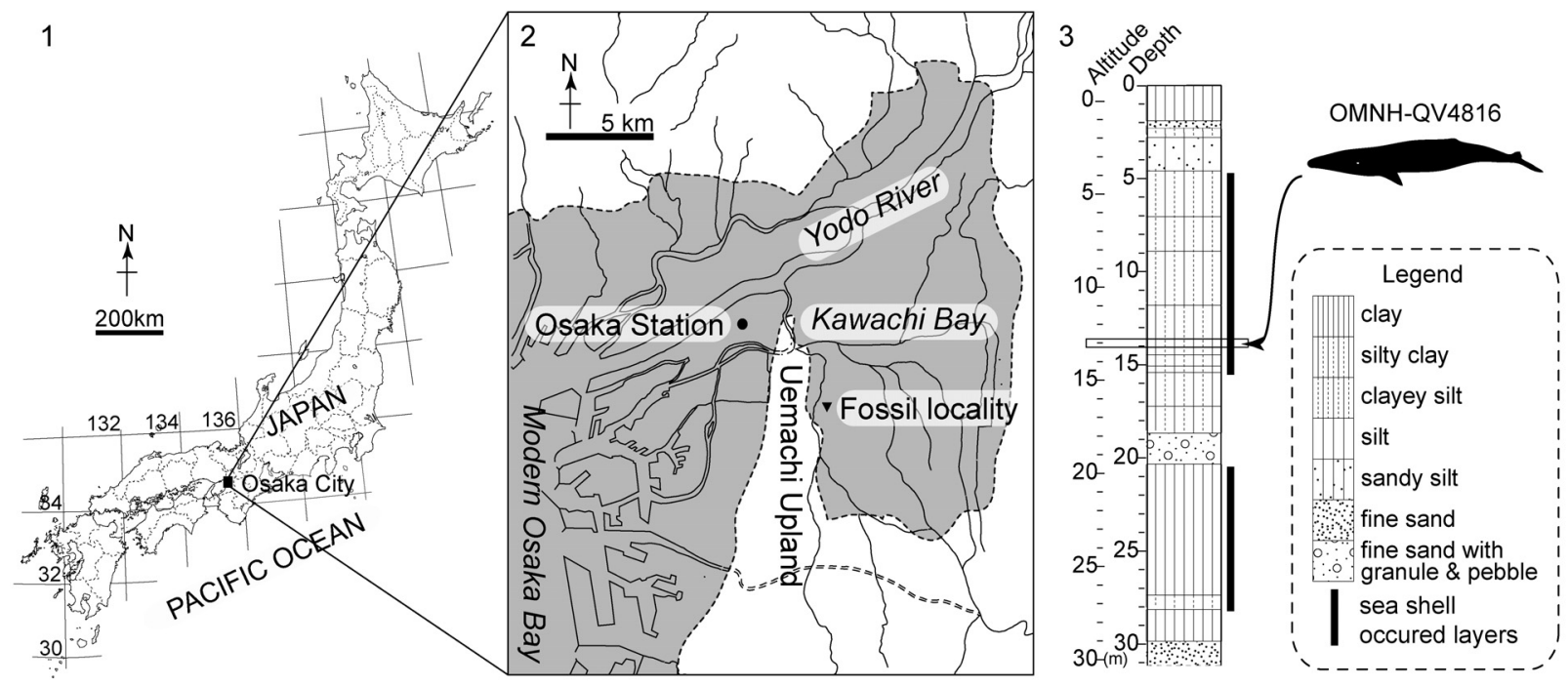

FIGURE 1. Locality maps and a stratigraphic section at the locality. 2, restoration of the Kawachi Bay following Osaka City Cultural Properties Association (2008). 3, the columnar section at OMNH-QV4816 locality, which was modified from a boring survey report in 1965.

remains were found from the sediments of the Kawachi Bay and Osaka Bay (Okazaki, 1975; Shindo, 1975; Taruno, 1984; Ogino, 1998). One of them, a skull (Osaka Museum of Natural History specimen, OMNH-QV4816; previously numbered as F2639) from the Osaka Plain was briefly described and identified as Balaenoptera acutorostrata based on measurement comparison with two juveniles and two adults of the species by Omura (1976).

Thanks to later skull morphological studies (Oishi, 1999; Wada et al., 2003; Oishi et al., 2009), identification of the Balaenopteridae has been improved. Here, we redescribe the skull with an unpublished rostrum part and identify its ontogeny and taxonomy. The OMNH-QV4816 adds a chronologically and geographically new record to a taxonomically confused whale species.

\section{Abbreviations}

NSMT - Department of Zoology, National Museum of Nature and Science, Japan. OMNH - Osaka Museum of Natural History. WMNH - Wakayama Prefectural Museum of Natural History.

\section{MATERIALS AND METHODS}

\section{Material}

OMNH-QV4816 preserves the skull such as maxilla, premaxilla, vomer, frontal, parietal, pterygoid, squamosal, alisphenoid, presphenoid, basisphenoid, supraoccipital, exoccipital, and basioccipital (Figure 2). The skull was found as ventral side up at the locality without the mandibles. Regarding Omura (1976), the skull was broken transversely, when the specimen was transported from the locality. On the dorsal surface, a few fragments of rounded bivalve's shells are attached.

\section{Locality}

OMNH-QV4816 was collected from 13.5 to 14 $\mathrm{m}$ deep at Ooimazato 3 Choume, Higashinari-ku on 11 August 1966, during subway construction. Omura (1976) reported the locality with a previous district name. The excavation was made during subway construction, so the locality is the eastern end of Imazato Station (Latitude $34^{\circ} 40^{\prime} 7.06 " \mathrm{~N}$, Longitude $\left.135^{\circ} 32^{\prime} 40.76 " E\right)$ (Figure 1).

\section{Horizon and Age}

The Osaka Plain is widely formed by an alluvium, the Namba Formation. The Namba Formation contains three parts; the lower alternation of sand and mud deposit, the marine clay middle part, and the sandysilt upper part (Mitamura and Hashimoto, 2004). Mitamura and Hashimoto (2004) used a database containing numerous boring survey data from the Osaka Plain. In the study, they reported altitude distribution of the base of the alluvium, Namba Formation (see figure 8 in Mitamura and Hashimoto, 2004). A columnar section from the locality shows that a marine soft clay layer lies between 4.6 and $15.4 \mathrm{~m}$ deep (Figure 1). The 


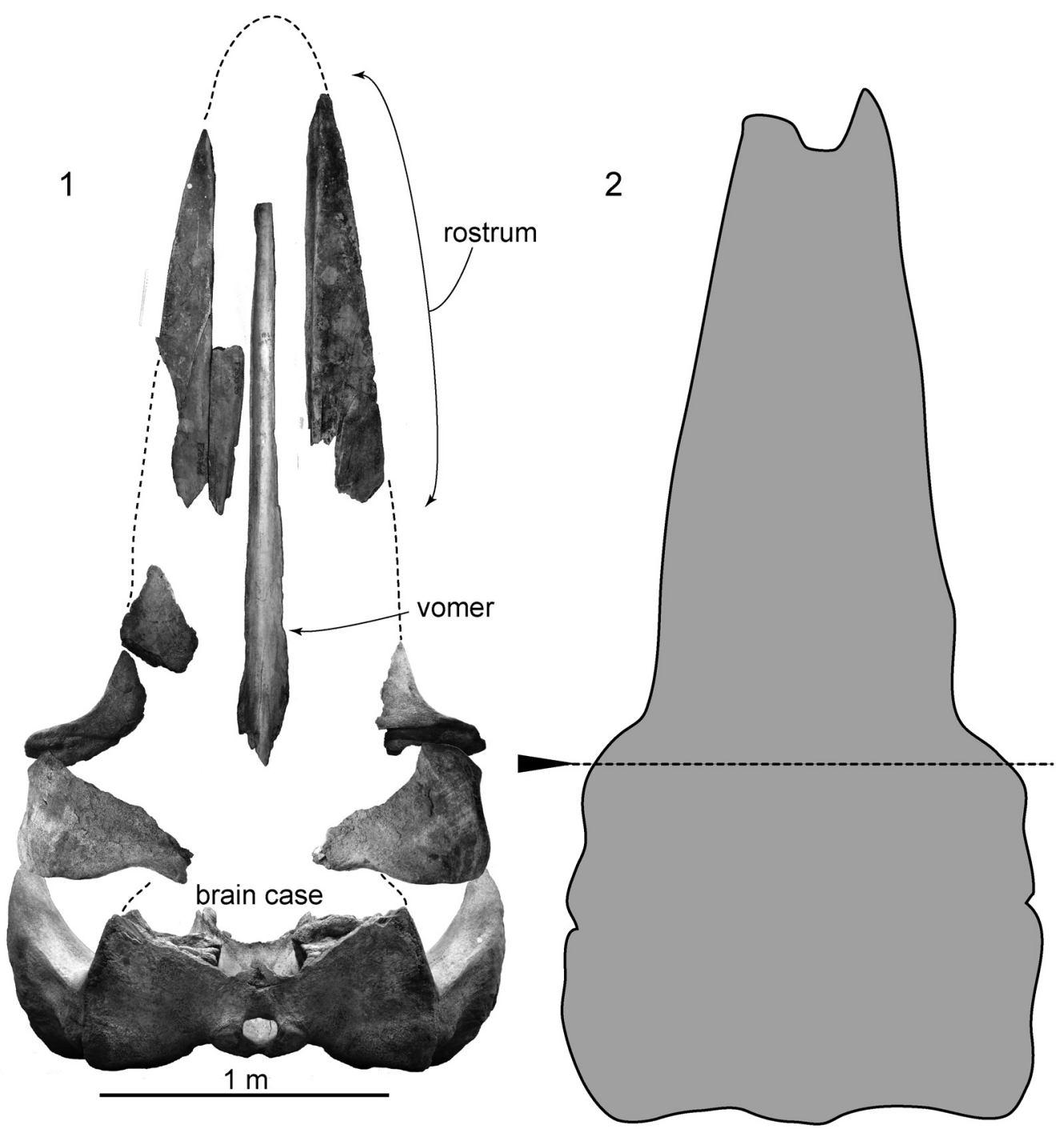

FIGURE 2. Skull, OMNH-QV4816 in dorsal view. 1, Restoration of the skull based on a photo, which was taken just before specimen was damaged by pulling up from the locality. 2, Line art was made from the photo. The outline of the skull is anteroposteriorly extended at the level of the antorbital process (arrow), result of a slide between the lose frontal and maxilla.

horizon of OMNH-QV4816 is lower part of the marine layer (13.5 to $14 \mathrm{~m}$ deep).

The altitude at the boring survey point was $+0.856 \mathrm{~m}$. Thus, the altitude of the remains is about $-13 \mathrm{~m}$. Sea level curves of Endo et al. (1989) with calculated C-14 age (Tanabe et al., 2012) allow to estimate that the age of sea level reaches around at the locality, rim of the Kawachi Bay is about 8800 BP. Thus the whale arrived at the locality after $8800 \mathrm{BP}$. The age of the highest sea level was about 7000 (Tanabe et al., 2012). The upper limit of the Namba Formation has been dated as 4000 to 5000 years ago at several localities in the Kawachi Bay (Kajiyama and Itihara, 1972; Chou,
2003). Thus, the estimated age of OMNH-QV4816 is about 8800 to 4000 years before present, which was the age of the Jomon transgression creating the Kawachi Bay (Figure 1).

\section{Methods}

Morphological terminology follows Mead and Fordyce (2009) unless stated.

\section{SYSTEMATIC PALEONTOLOGY}

Order CETACEA Brisson, 1762

Unranked taxon NEOCETI Fordyce and de Muizon, 2001 


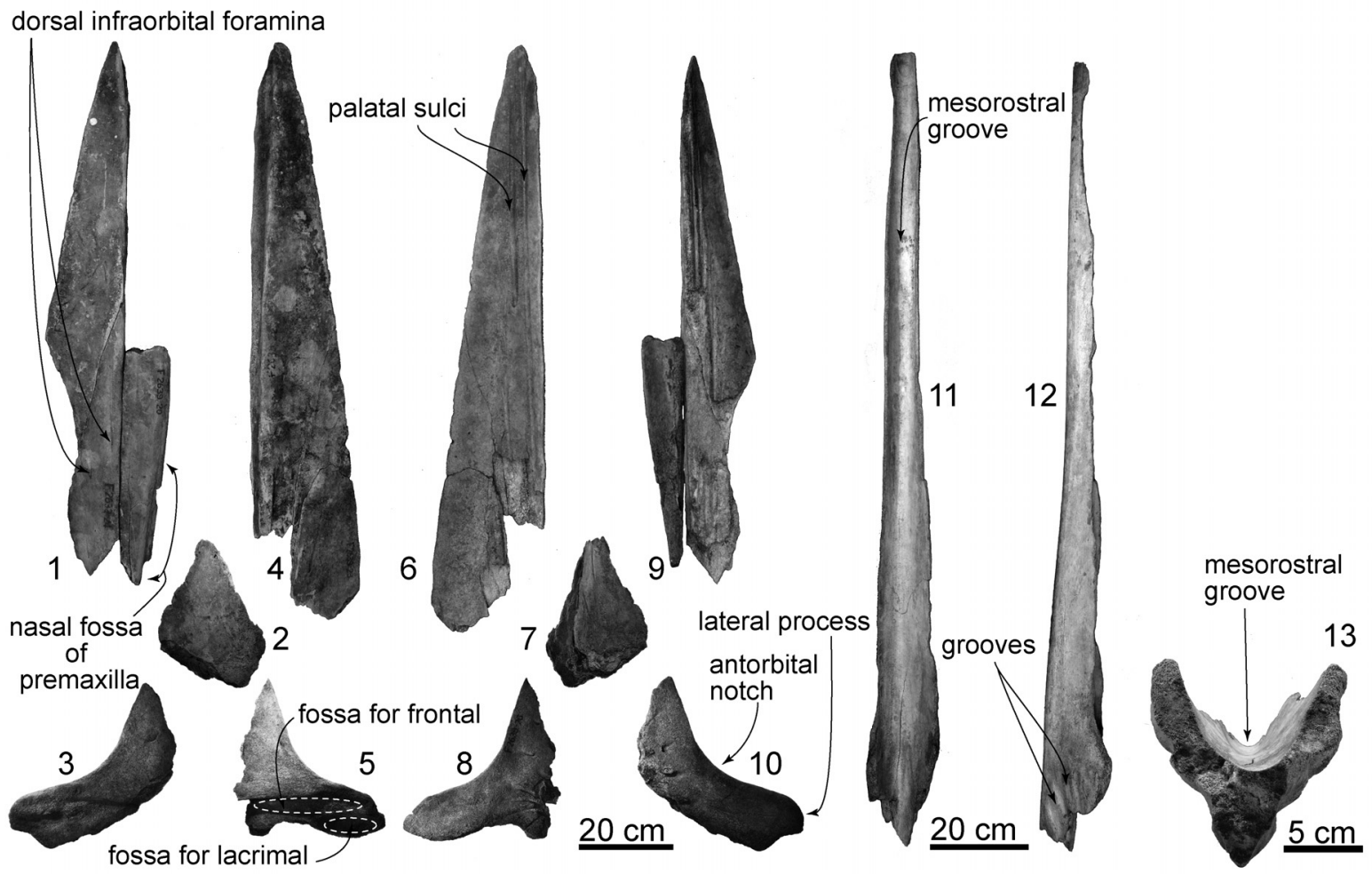

FIGURE 3. Maxilla, premaxilla and vomer, OMNH-QV4816. 1, left anterior part of maxilla and premaxilla. 2, left middle part of maxilla. 3, left preorbital region of maxilla. 4, right anterior part of maxilla. 5, right preorbital region of maxilla. 15 , in dorsal view. 6, right anterior part of maxilla. 7, right preorbital region of maxilla. 8, left anterior part of maxilla and premaxilla. 9, left middle part of maxilla. 10, left preorbital region of maxilla. 6-10, in ventral view. 11 to 13, vomer. 11, in dorsal view. 12, in left lateral view. 13, in posterior view.

\section{Suborder MYSTICETI Flower, 1864 \\ Family BALAENOPTERIDAE Gray, 1864 \\ Genus Balaenoptera Lacépéde, 1804 \\ Balaenoptera edeni Anderson, 1879}

(Figures 2-9, Table 1)

Diagnosis. OMNH-QV4816 is identified as Balaenoptera edeni based on having a large alisphenoid, which contacts with the squamosal widely (Oishi, 1999). B. brydei and B. omurai differ from B. edeni having a much smaller alisphenoid (Wada et al., 2003; Oishi et al., 2009). B. borealis differs from $B$. edeni and $B$. acutorostrata having the alisphenoid, which forms the medial part of the optic canal (Muller, 1954; Oishi, 1999).

\section{General description}

Ontogeny. The posterior process of the periotic is in situ but is not fused to the squamosal in ventral view. Fused posterior process of the periotic to the skull had been suggested as a condition of adults (Kasuya, 1973; Geisler and Luo, 1996). The posterior process of OMNH-QV4816 suggests that the individual is not a fully adult. Thus, OMNH-QV4816 is subadult.

Maxilla. The preserved maxillae are separated into rostral (1060 mm long) and orbital regions (181 $\mathrm{mm}$ long) (Figure 3). The rostral part shows more or less straight lateral margin with a posteriorly widen triangular anterior tip. On the dorsal side, dorsal infraorbital foramina open anteriorly as deep grooves. There is a weakly excavated and anteroposteriorly long area for the premaxilla on the medial surface. In ventral view, anteroposteriorly long and deep palatal foramina and sulci run between the median line and the palatal margin. The ventral side is excavated and shows at least three anteroposteriorly long palatal sulci. In the cross section, the rostrum part of the maxilla is medially high, laterally thin triangular. The medial margin of the maxilla (70 $\mathrm{mm}$ high) shows weakly excavated plain for the contact of the premaxilla.

The preserved posterior part of the maxilla shows well-projected lateral process. Anterior to the process, there is a very shallow antorbital notch. Posterior to the antorbital notch, there are 


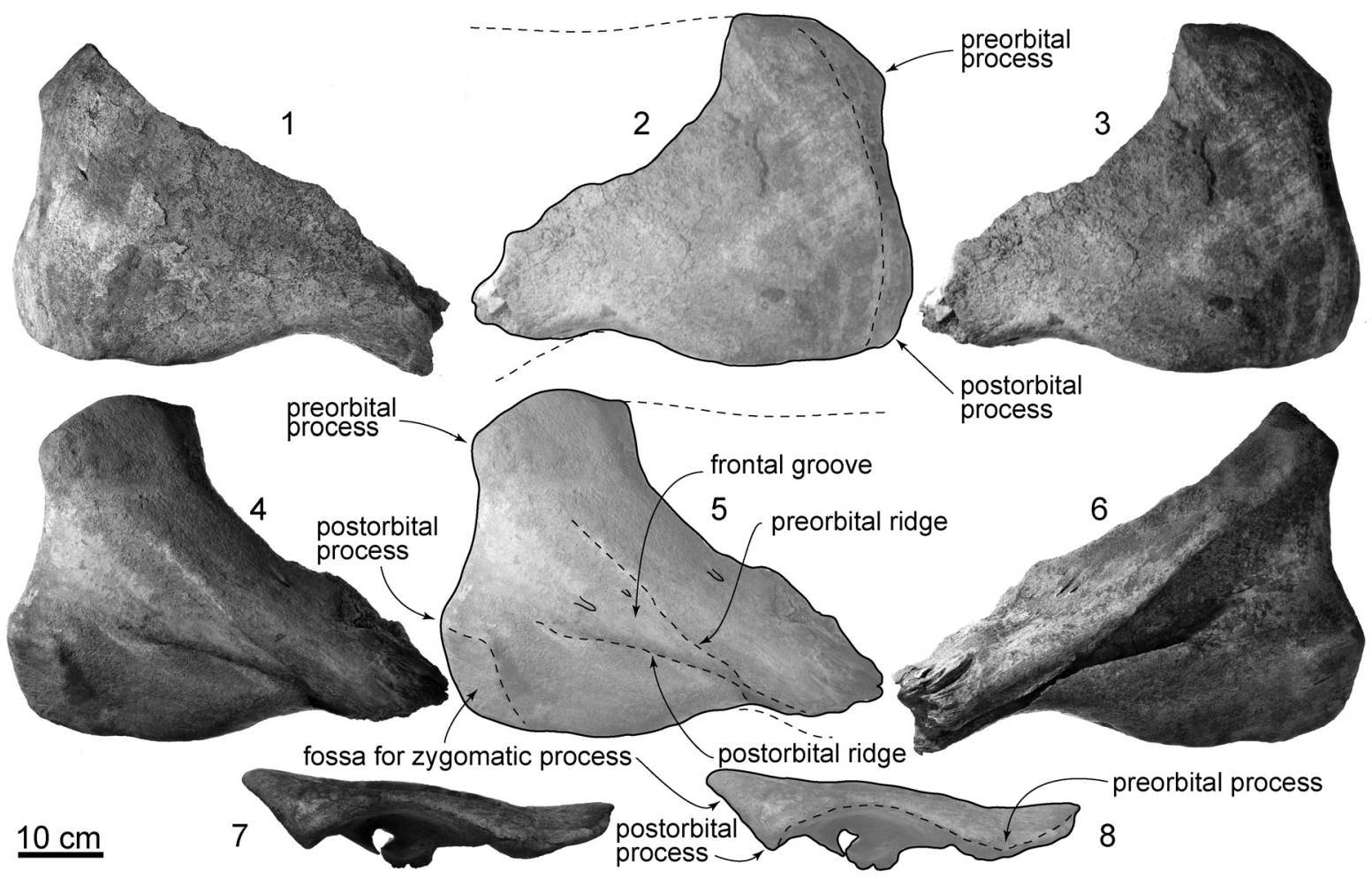

FIGURE 4. Frontals, OMNH-QV4816. 1, left in dorsal view. 2 and 3, right in dorsal view. 2, line art. 3, photo. 4 and 5, right in ventral view. 4 , photo. 5 , line art. 6 . right in ventral view. 7 and 8 , in right lateral view. 7 , photo. 8 , line art.

depressed areas for the frontal anteriorly and lacrimal posteriorly. Lateral to the antorbital notch, a supposed most posteriorly located dorsal infraorbital foramen opens laterally and its shape is anteroposteriorly long elliptical $(26.5 \mathrm{~mm}$ long and $10.5 \mathrm{~mm}$ height). Most of the infraorbital plate is broken away.

Premaxilla. Only a part of left premaxilla is preserved (Figure 3). The preserved premaxilla is anteriorly weakly convex to dorsal and posteriorly narrow. Its posteromedial surface forms a vertical wall, which constitutes a part of the nasal fossa, which is a place for the depressor alae nasi (Mead and Fordyce, 2009; Buono et al., 2015; Marx et al., 2016). Thus, the preserved premaxilla probably is a middle portion. Ventrally, the premaxilla is excavated dorsally and forms a dorsolateral part of the mesorostral groove. Medial surface is anteriorly flat, but has anteroposteriorly long depression for the contact with the maxilla.

Frontal. The frontal is laterally wide fan shape (Figure 4). The dorsal surface is slightly concaved. In dorsoventral view, the preorbital and postorbital processes show weakly excavated larteral margin of the orbital region medially. These processes are blunt. The postorbital process has a fossa for the anterior tip of the zygomatic process. There are low preorbital and postorbital ridges on the ventral surface of the frontal, which run from these processes to the medial side. The posterolateral margin of the posterior process is extended posteriorly. In lateral view, the postorbital process is triangle and projects posteroventrally. The process is higher than the preorbital process, which is also triangular.

Vomer. The vomer is separated into a long rostral portion (1690 mm long) (Figure 3) and dorsoventrally thin posterior portion under the brain case (Figure 6). The anterior portion of the vomer is thinner than the posterior part, and dorsally opened $U$ shape in the cross section. Anterior part of the ventral surface is flat and exposes in ventral view between the maxillae. Posterior part of the rostral portion of the vomer is widened and shows several anteroposteriorly long grooves.

The posterior portion of the vomer is dorsoventrally low sheet and has more or less parallelsided lateral margins in ventral view. The posterior broken section shows the vomerine crest at the center $(26.5 \mathrm{~mm}$ maximum height and $114.0 \mathrm{~mm}$ 


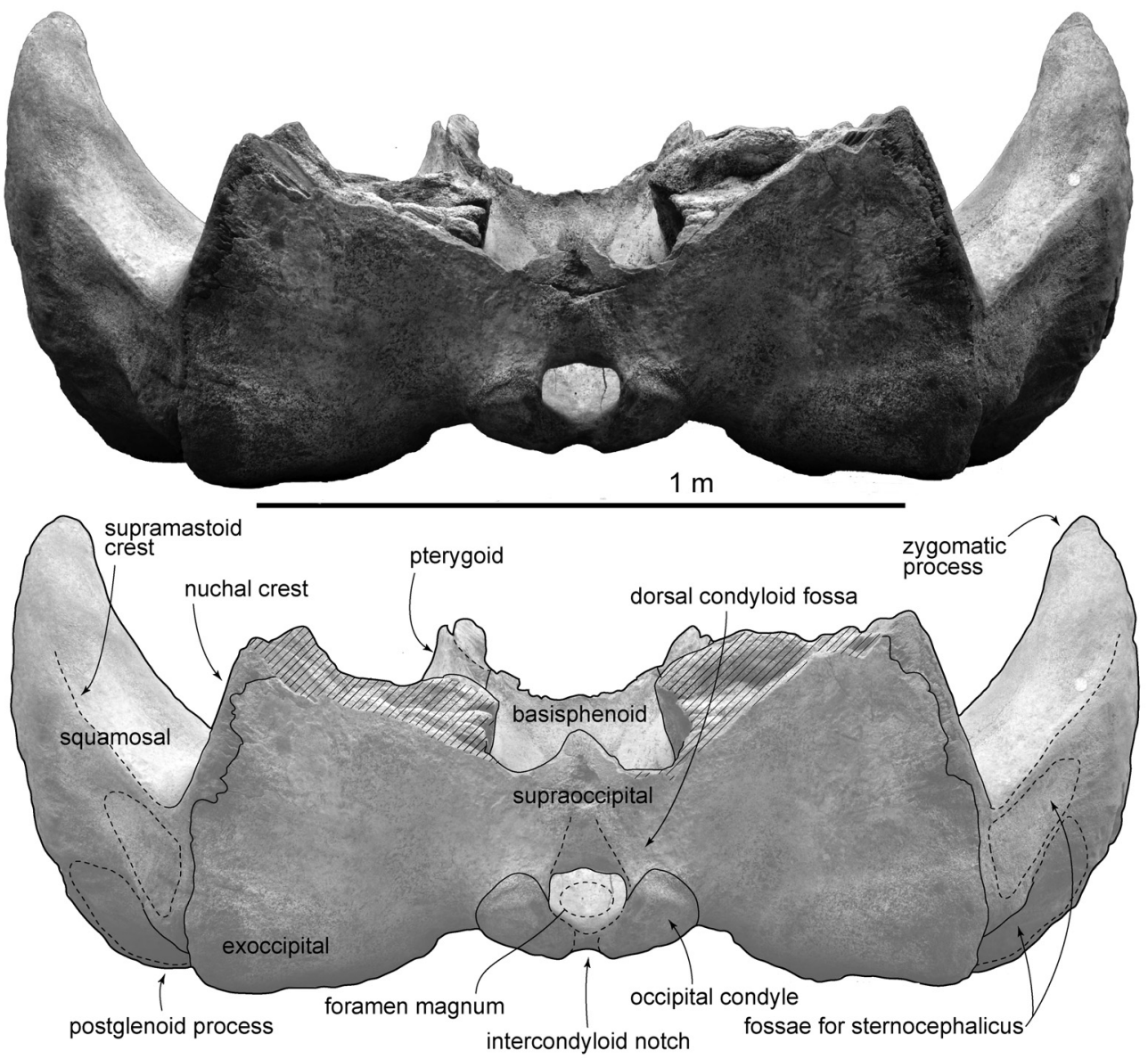

FIGURE 5. Posterior part of skull, OMNH-QV4816 in dorsal view. Top, photo. Bottom, line art.

width). The posterior end of the vomer wraps the basisphenoid.

Parietal. The preserved posterior part of the parietal forms the posteromedial part of the temporal fossa, which is vertical and weakly excavated (Figure 9). The parietal contacts with the squamosal posteriorly, and the large alisphenoid ventrally.

A small exposure of the parietal locates lateral to the alisphenoid, anterior and medial to the squamosal. The parietal faces the fossa for the periotic medially. The part includes a few laterally excavated pits.

Squamosal. The squamosal has a long and anteriorly tapered zygomatic process and posteroventrally projected blunt postglenoid process.

The anterior part of the zygomatic process projects anteriorly, and is narrowing gradually in ventral and lateral views. The ventral surface of the zygomatic process is weakly convex, which is an area for the masseter deep (Marx et al., 2016), and its anterior tip is tilted ventrally a bit. A faint supramastoid crest runs on the dorsal surface of the zygomatic process. Anterior to the base of the zygomatic process, at a posterior part of the temporal fossa, a deep squamosal cleft runs transversely. At the posterior part, the lateral surface of the zygomatic process shows faint shallow fossae, which are the fossae for the sternocephalicus. The posteroventrally projected postglenoid process is narrowing ventrally.

In ventral view (Figure 6), the squamosal has a low spiny process, which is the border for the periotic. The falciform process is absent. An almost closed foramen pseudovale locates lateral to the pterygoid sinus fossa, and is formed by the both squamosal and pterygoid. The almost closed foramen pseudovale is filled by an additional pterygoid bone, and is more or less closed. The mandibular fossa is flat and smooth. Posterior to the postglenoid process, the squamosal forms a ventrally widely opened external auditory meatus $(27 \mathrm{~mm}$ long and $242 \mathrm{~mm}$ wide). The posterior part of the squamosal contacts to the long and anteroposteri- 


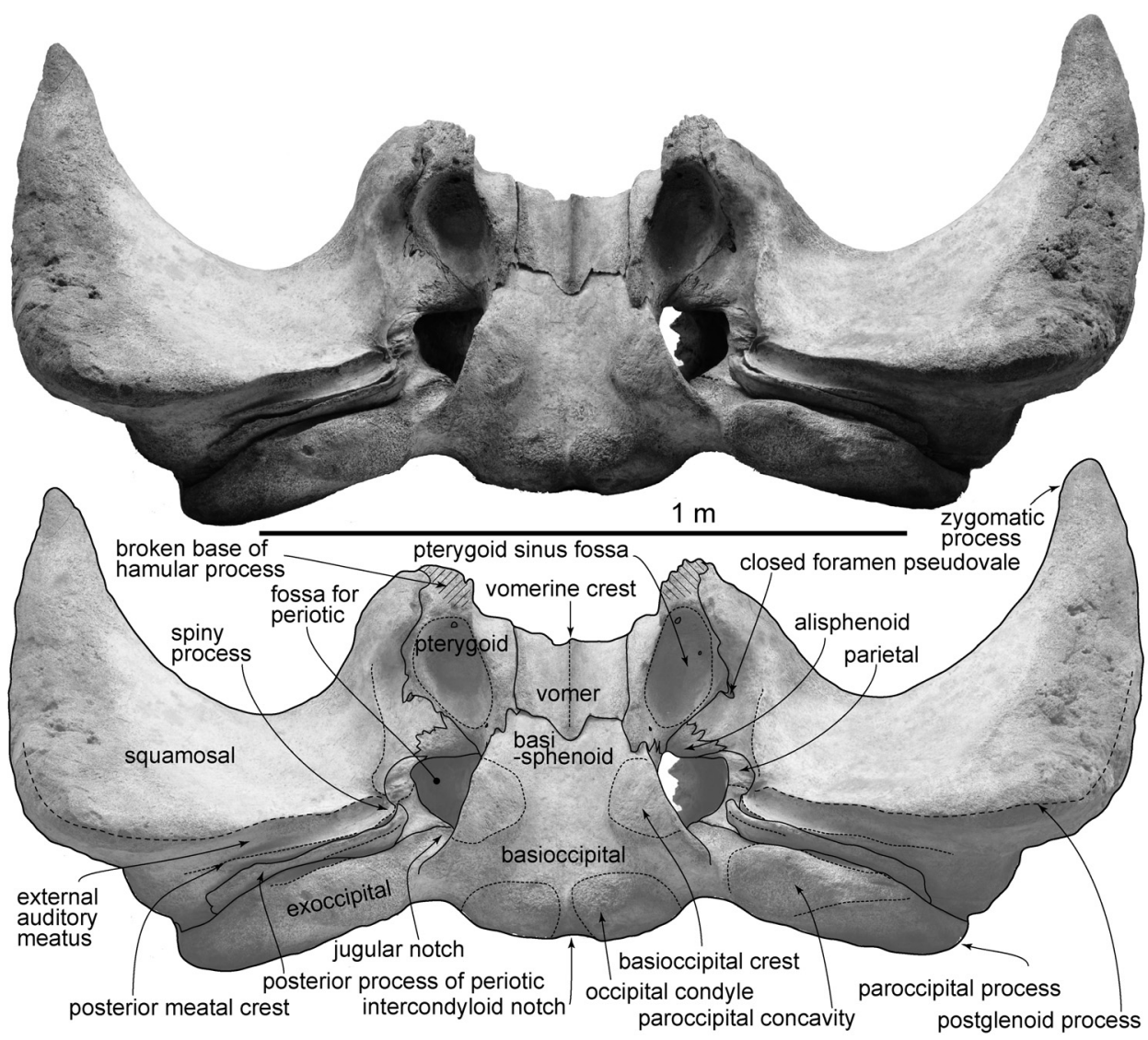

FIGURE 6. Posterior part of skull, OMNH-QV4816 in ventral view. Top, photo. Bottom, line art.
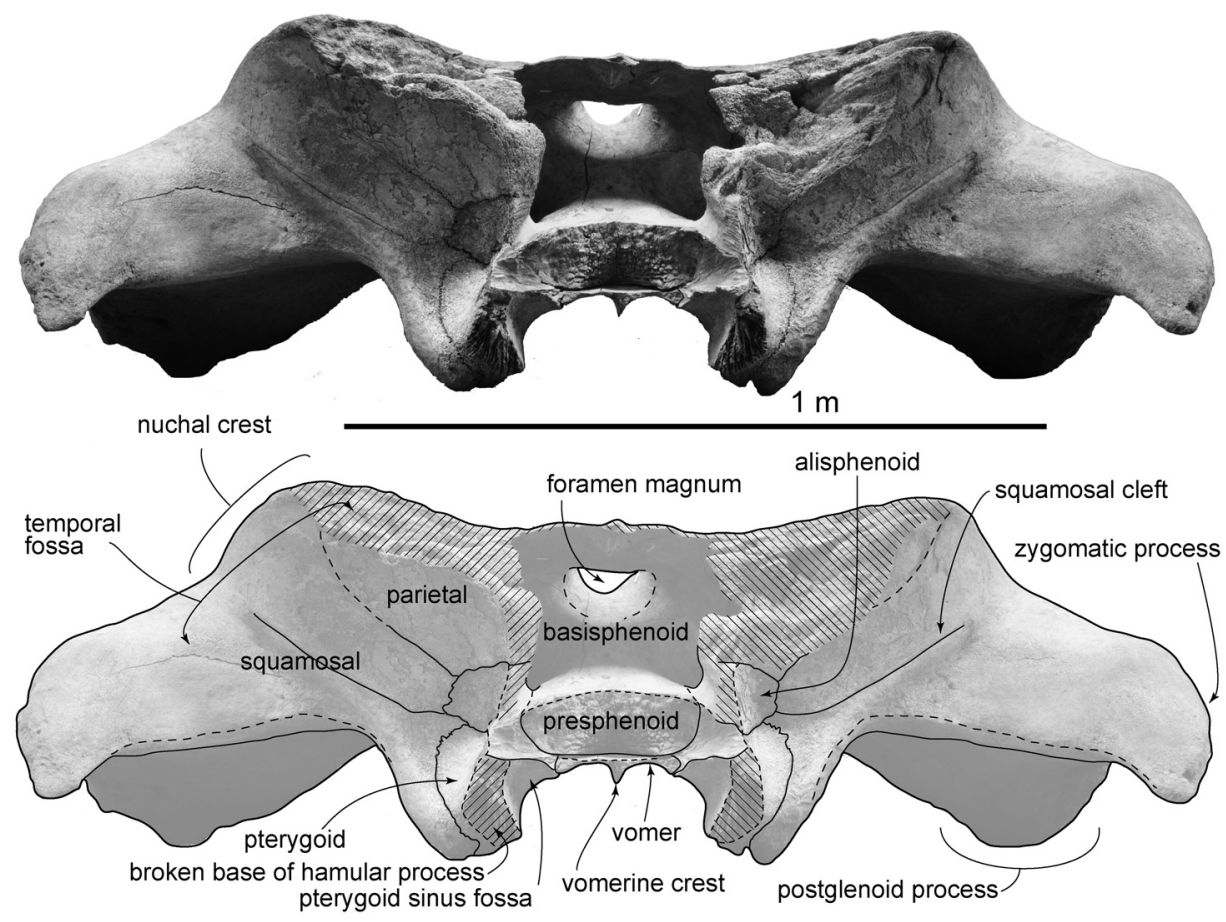

FIGURE 7. Posterior part of skull, OMNH-QV4816 in anterior view. Top, photo. Bottom, line art. 

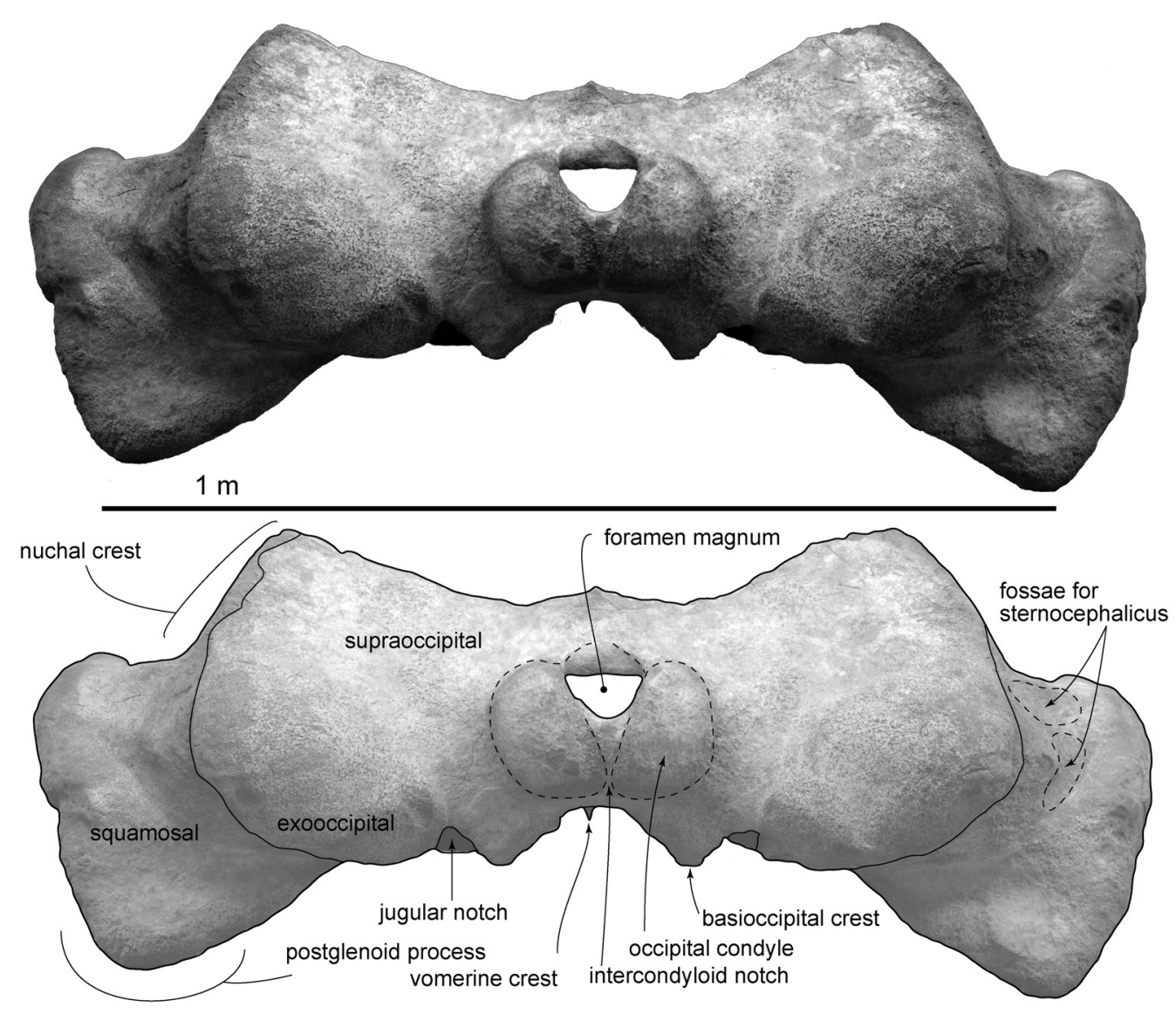

FIGURE 8. Posterior part of skull, OMNH-QV4816 in posterior view. Top, photo. Bottom, line art.

orly short plate-like fused posterior processes of the periotic and bulla.

Pterygoid. The pterygoid locates medially to the squamosal. Anteriorly, the pterygoid has a broken base of the hamular process and its broken section shows laterally convex crescentic shape. The pterygoid has an anteroposteriorly long elliptical, huge, and shallow pterygoid sinus fossa $(130 \mathrm{~mm}$ long and $85 \mathrm{~mm}$ wide). The fossa contains a few foramina.

Alisphenoid. The large squared lateral exposure of the alisphenoid contacts with the squamosal widely laterally, parietal dorsally, presphenoid medially and the pterygoid ventrally (Figure 7). The lateral exposure of the alisphenoid is rugose, flat and slightly far back compare to the other bones' surfaces. The squamosal cleft continues to the ventral border of the alisphenoid. The alisphenoid forms an anterior part of the braincase.

There is a ventral exposure of the alisphenoid, lateral to the pterygoid, posterior to the foramen pseudovale but is not contacted. Posteriorly, the alisphenoid forms an anterior border of the fossa for the periotic.

Basisphenoid/presphenoid. The basisphenoid/ presphenoid suture is fused. The presphenoid locates anterior to the basisphenoid (Figure 7), dorsal to the vomer. In anterior view, the presphenoid shows mediolaterally wide elliptical. The basisphenoid locates posterior to the vomer, and its overall shape is anteriorly wider trapezoid (Figure 6 ). The posterior border of the basisphenoid with basioccipital is completely fused suture. The lateral borders contacts with the pterygoid.

Supraoccipital. The preserved ventral part of the supraoccipital has wide lateral borders, which are weakly curved nuchal crests (Figure 8 ). The dorsal surface of the supraoccipital is flat. The external occipital crest was worn, but its broken surface shows that the crest runs dorsoventrally on the median line.

Basioccipital. The basioccipital is posteriorly wide trapezoid in ventral view with posteriorly just swollen (non peddicle) occipital condyles, which are ventrally slightly wider elliptical (Figure 6). Between 


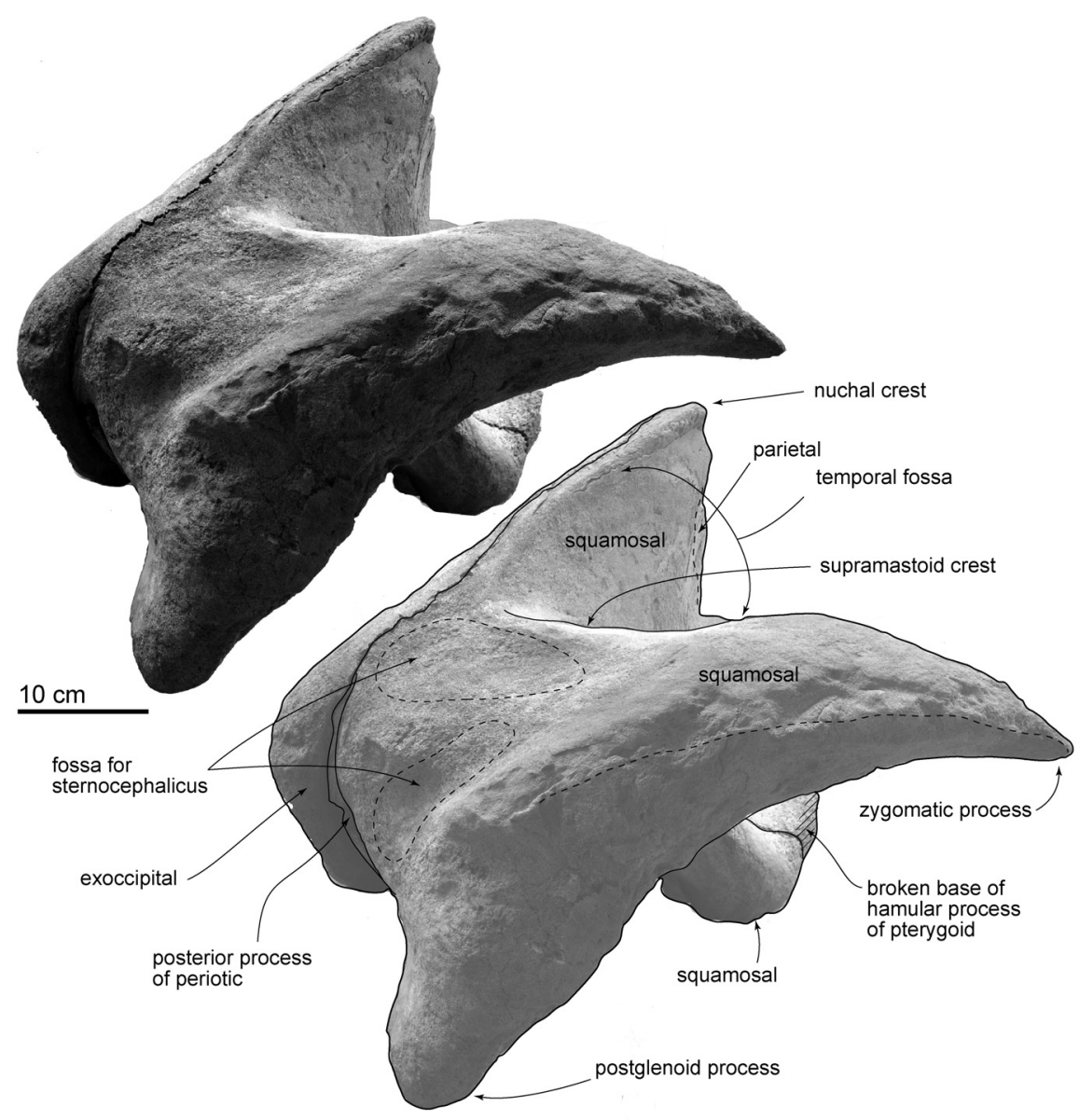

FIGURE 9. Posterior part of skull, OMNH-QV4816 in right lateral view. Top, photo. Bottom, line art.

the condyles, there is a shallow intercondyloid notch. At the lateral border of the basioccipital, there are a couple of swollen basioccipital crests. Between the crests, the basioccipital basin is flat. The posterolateral end of the basioccipital forms widely opened jugular notch with the exoccipital.

Exoccipital. In dorsal view (Figure 5), the lateral ends of the exoccipital extend posterolaterally. In ventral view, the exoccipital is $58 \mathrm{~mm}$ long and 270 $\mathrm{mm}$ wide, and contacts to the posterior process of the periotic. On the ventral surface of the exoccipital, there is a mediolaterally long triangular paroccipital concavity. The paroccipital process narrows at the lateral ends. The exoccipital/squamosal suture is wavy and opened.

Periotic and bulla. The posterior processes of the periotic and bulla preserve as fused condition only a mediolaterally long posterior process in situ (Figure 6). The posterior process is dorsoventrally high and anteroposteriorly thin plate.
TABLE 1. Measurements in $\mathrm{mm}$ of OMNH-QV4816 skull and periotic. For skull and mandible, distances are either horizontal or vertical..

\begin{tabular}{lc}
\hline \multicolumn{1}{c}{ Skull } & $\begin{array}{c}\text { Measure } \\
\text { (mm) }\end{array}$ \\
\hline Preserved length of skull & 537 \\
Bizygomatic width & 1170 \\
Bicondylar width & 195 \\
Preserved frontal length & 352 \\
Preserved frontal width & 565 \\
Posterior process of periotic maximum & 226 \\
mediolateral length & \\
Posterior process of periotic maximum & 26 \\
anteroposterior length & \\
\hline
\end{tabular}


TANAKA \& TARUNO: A JAPANESE HOLOCENE WHALE

TABLE 2. Records of Balaenoptera edeni and B. brydei with molecular data and/or morphological specimens around Japan, and in the Seto Inland Sea including the Osaka Bay. These data are taken from Marine Mammal Stranding Database of the National Museum of Nature and Science (www.kahaku.go.jp/research/db/zoology/marmam/drift/ index.php) and IDs in this table are the ones in the database.

\begin{tabular}{|c|c|c|c|c|c|}
\hline & Identification & Age or date & Locality & Specimen & $\begin{array}{c}\text { ID and specimen } \\
\text { number }\end{array}$ \\
\hline 1 & B. edeni & $\begin{array}{l}8000 \text { to } 4400 \\
\text { years before }\end{array}$ & Osaka City & Fossil skull & OMNH-QV4816 \\
\hline 2 & B. edeni & 11 Nov 1995 & $\begin{array}{l}\text { Shimotsu Port, } \\
\text { Wakayama City, } \\
\text { Wakayama Prefecture }\end{array}$ & Skeleton & $\begin{array}{c}\text { Oishi et al., } 2009 \text { 1794, WMNH 1998- } \\
\text { ver-3 }\end{array}$ \\
\hline 3 & B. edeni & 22 Oct 2001 & $\begin{array}{l}3.6 \text { km southwest to } \\
\text { Inge Island, Awaji City, } \\
\text { Hyogo Prefecture }\end{array}$ & DNA sample & 3006 \\
\hline 4 & B. edeni & 27 Aug 1978 & $\begin{array}{l}8 \mathrm{~km} \text { off Aki Town, } \\
\text { Ooita Prefecture }\end{array}$ & $\begin{array}{l}\text { Skull at Kisuki City } \\
\text { Museum }\end{array}$ & 498 \\
\hline 5 & B. edeni & 17 Jan 2007 & $\begin{array}{l}\text { Hitachinaka Port, } \\
\text { Hitachinaka City, } \\
\text { lbaraki Prefecture }\end{array}$ & DNA sample & 5253 \\
\hline 6 & B. edeni & 12 May 1994 & $\begin{array}{l}\text { Imouto Island } \\
\text { OgasawaraVillage, } \\
\text { Tokyo }\end{array}$ & DNA sample & 1678 \\
\hline 7 & B. edeni & 21 Jun 2000 & $\begin{array}{l}\text { Off Daio Cape, Shima } \\
\text { City, Mie Prefecture }\end{array}$ & DNA sample & 2638 \\
\hline 8 & B. edeni & 27 Dec 2002 & $\begin{array}{l}\text { Fukumitsu, Ooda City, } \\
\text { Shimane Prefecture }\end{array}$ & $\begin{array}{l}\text { DNA sample, } \\
\text { Skeleton at Shimane } \\
\text { AQUAS Aquarium }\end{array}$ & 3455 \\
\hline 9 & B. edeni & 20 Aug 1998 & $\begin{array}{l}\text { Tsunoshima, } \\
\text { Shimonoseki City, } \\
\text { Yamaguchi Prefecture }\end{array}$ & DNA sample & 2235 \\
\hline 10 & B. edeni & 8 Nov 1994 & $\begin{array}{l}\text { Nase, Kitaura Town, } \\
\text { Miyazaki Prefecture }\end{array}$ & $\begin{array}{l}\text { Skeleton at Kitaura } \\
\text { Town }\end{array}$ & 1707 \\
\hline 11 & B. edeni & 31 Jan 2002 & $\begin{array}{l}\text { Fukue Island, Gotou } \\
\text { City, Nagasaki } \\
\text { Prefecture }\end{array}$ & DNA sample & 3107 \\
\hline 12 & B. edeni & 7 Jun 2006 & $\begin{array}{l}\text { Takado Beach, } \\
\text { Amakusa City, } \\
\text { Kumamoto Prefecture }\end{array}$ & $\begin{array}{l}\text { Skull at Kumamoto } \\
\text { City Museum }\end{array}$ & 5068 \\
\hline 13 & B. edeni & 24 May 2004 & $\begin{array}{l}\text { Marushima Port, } \\
\text { Minamata City, } \\
\text { Kumamoto Prefecture }\end{array}$ & DNA, Skeleton & $\begin{array}{l}\text { 4128, NSMT-M } \\
33622\end{array}$ \\
\hline 1 & B. brydei & 5 Oct 2002 & $\begin{array}{l}\text { Natori City, Miyagi } \\
\text { Prefecture }\end{array}$ & $\begin{array}{l}\text { DNA sample, } \\
\text { Skeleton }\end{array}$ & $\begin{array}{l}\text { 3392, NSMT- } \\
\text { M33072 }\end{array}$ \\
\hline 2 & B. brydei & 15 May 2007 & $\begin{array}{l}\text { Nakasode, Sodegaura } \\
\text { City, Chiba Prefecture }\end{array}$ & $\begin{array}{l}\text { DNA sample, } \\
\text { Skeleton }\end{array}$ & 5400 \\
\hline 3 & B. brydei & 1953 & No record & Skeleton & NSMT-M03538 \\
\hline
\end{tabular}

\section{DISCUSSION}

\section{Confused Taxonomical History of Balaenoptera edeni and B. brydei, and their Morphological Identifications}

B. edeni and $B$. brydei have been thought as a species (Junge, 1950; Muller, 1954) or two species
(Rice, 1998; Oishi, 1999). The confused taxonomical history of Balaenoptera edeni and B. brydei made difficulties when establishing their basic knowledge. Recent molecular phylogenies support independency of the three species; $B$. edeni, $B$. brydei, and B. borealis (Wada et al., 2003; Sasaki et al., 2006; McGowen et al., 2009), and these 


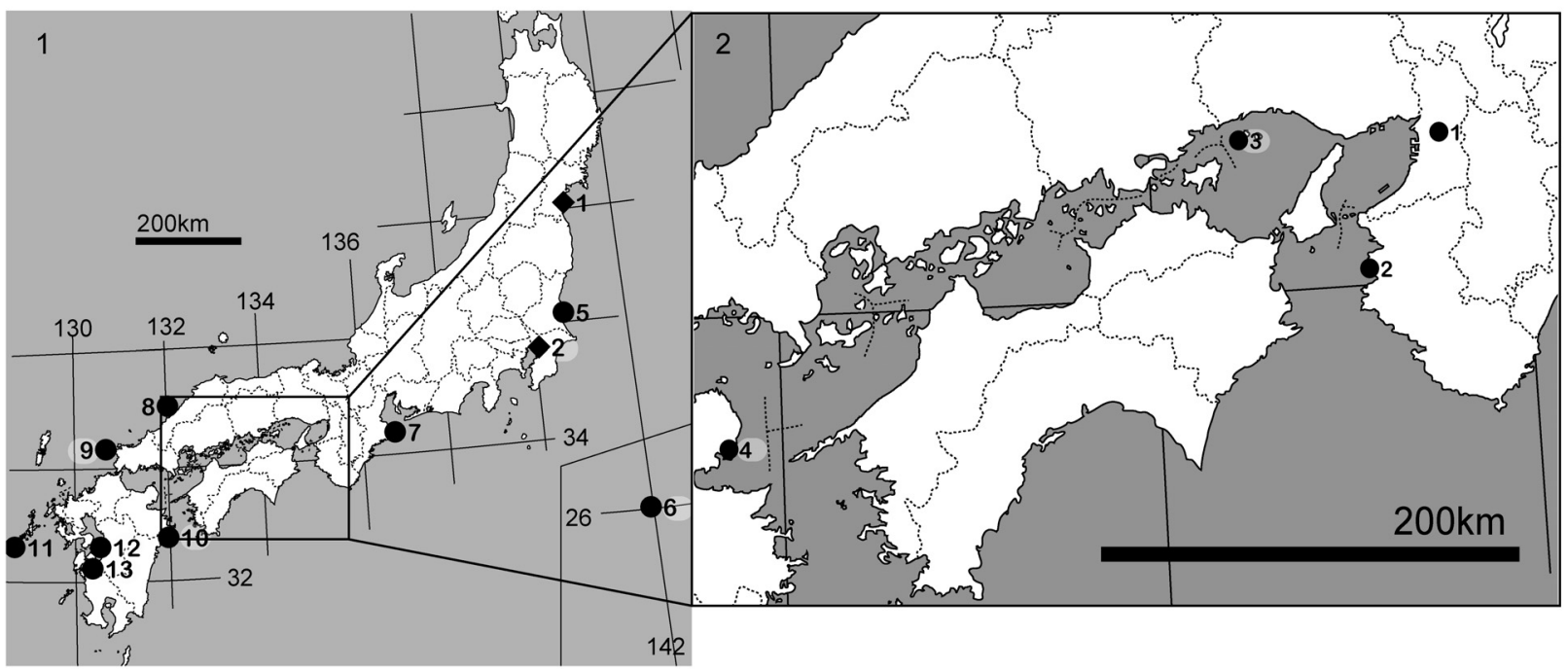

FIGURE 10. Map showing records of Balaenoptera edeni and B. brydei. 1, around Japan. 2, in the Seto Inland Sea including the Osaka Bay. See Table 2.

studies have been supported (Deméré et al., 2005).

Because of confused taxonomical history of $B$. edeni and $B$. brydei in the research history as above, Balaenoptera edeni distribution is not well known (Rice, 1998). Some literatures combine distribution of the two species into one. Kato et al. (1996) suggested that there are two stocks of "Bryde's whales" around Japan (East China Sea stock and Western North Pacific stock). As Marine Mammal Stranding Database of the National Museum of Nature and Science (www.kahaku.go.jp/research/db/zoology/marmam/ drift/index.php) shows, DNA examinations reveal that these stocks can be separated into the two species, B. edeni (equivalent to East China Sea stock) and B. brydei (equivalent to Western North Pacific stock). So, now so-called Bryde's whale distribution is more certain with identifications using DNA analyses.

There are $13 B$. edeni and three $B$. bridei DNA and/or skeleton records around Japan regarding the database (Table 2). Records of $B$. edeni are mainly in western Japan, and B. bryde's records are in eastern Japan (see also Figure 10). Only four of $13 B$. edeni have been recorded in the Seto Inland Sea, even the area has high density of human activities, which is related to opportunities of finding whales.

\section{A New Data for Considering B. edeni's Distribution}

DNA analysis is a powerful tool to identify the species, but thinking about remains, collagen fin- gerprinting for fragmental materials (Buckley et al., 2014; Buckley et al., 2017) and osteological examination are helpful for identification. Here, we apply morphological examination with some measurements (see Table 3), because the specimen preserves diagnoses of the species.

Osteological identification of the genus Balaenoptera has been discussed by several previous studies (Junge, 1950; Muller, 1954; Oishi, 1999; Wada et al., 2003; Oishi et al., 2009). Detailed osteological studies fixed confused Balaenoptera edeni and $B$. brydei identifications. For example, Oishi (1999) reported a feature of Balaenoptera edeni such as having a large alisphenoid, which contacts with the squamosal widely. Later, Wada et al. (2003) and Oishi et al. (2009) differentiated closely related $B$. brydei and $B$. omurai from $B$. edeni using a feature that alisphenoid size. Thus, the alisphenoid size and contacts to the other bones is a useful part to identify.

Omura (1976) identified OMNH-QV4816 as Balaenoptera acutorostrata based on measurement comparison with two juveniles and two adults of the species. Later, a graduation thesis of Ogino (1998) reexamined OMNH-QV4816 as Balaenoptera sp. based on having narrow occipital condyles. Thanks to later osteological studies, OMNHQV4816 is identified as Balaenoptera edeni based on the alisphenoid shape in this study (see diagnosis). Especially the height of the alisphenoid allows identifying $B$. edeni from the other Balaenoptera spp. (see Table 3). In addition, a line art (right in Figure 3, which was drawn from a photo of OMNHQV4816 on a newspaper article just before digging 
TABLE 3. Measurements in mm of Balaenoptera spp. skulls, distances are either horizontal or vertical. Having high alisphenoid is a diagnositic feature for $B$. edeni.

\begin{tabular}{|c|c|c|c|c|c|c|c|}
\hline Scientific name & $\begin{array}{l}\text { Specimen } \\
\text { number }\end{array}$ & $\begin{array}{l}\text { Bizygomatic } \\
\text { width }\end{array}$ & $\begin{array}{c}\text { Zygomatic } \\
\text { process } \\
\text { maximum } \\
\text { height }\end{array}$ & $\begin{array}{c}\text { Zygomatic } \\
\text { process } \\
\text { maximum } \\
\text { length }\end{array}$ & $\begin{array}{c}\text { Alisphenoid } \\
\text { maximum } \\
\text { height }\end{array}$ & $\begin{array}{c}\text { Alisphenoid } \\
\text { maximum } \\
\text { length }\end{array}$ & $\begin{array}{c}\text { Occipital } \\
\text { condyle } \\
\text { width }\end{array}$ \\
\hline B. edeni & OMNH-QV4816 & 120.0 & 24.5 & 50.0 & 6.5 & 9.0 & 24.0 \\
\hline B. edeni & NSMT-M33622 & 77.0 & 23.5 & 30.0 & 4.0 & 8.5 & 20.0 \\
\hline B. brydei & NSMT-M33072 & 86.5 & 26.5 & 30.0 & 1.0 & 5.0 & 19.0 \\
\hline B. brydei & NSMT-M03538 & 140.0 & 26.0 & 50.5 & 1.5 & 10.0 & 23.0 \\
\hline B. omurai & NSMT-M32505 & 143.5 & 37.5 & 55.5 & 1.5 & 3.0 & 20.5 \\
\hline B. omurai & NSMT-M32992 & 88.5 & 26.0 & 28.5 & 1.5 & 3.0 & 18.0 \\
\hline B. acutorostrata & NSMT-M52713 & 117.5 & 40.5 & 42.0 & 3.0 & 9.0 & 21.0 \\
\hline B. acutorostrata & NSMT-M42450 & 88.0 & 28.0 & 30.5 & 1.5 & 6.0 & 18.0 \\
\hline B. acutorostrata & OMNH M3400 & 62.0 & 24.0 & 23.0 & 1.5 & 6.5 & 15.5 \\
\hline
\end{tabular}

up) shows that OMNH-QV4816 has a broader rostrum than the ones of Balaenoptera acutorostrata. This difference of rostrum proportion was mentioned by Nishiwaki (1965).

OMNH-QV4816 adds a chronologically and geographically new record to the species. No fossil $B$. edeni records have been reported by now (Deméré et al., 2005). Compare to the modern distribution of $B$. edeni, which distributes the East China Sea and off Kochi, the record of OMNHQV4816 from Osaka suggests that the modern distribution probably had already established about 8800 to 4000 years before. More remains of $B$. edeni, which are morphologically diagnosable specimens, will provide better resolution of their distribution in the past.

\section{CONCLUSION}

The remains of the Balaenoptera edeni skull from the Holocene (about 8800 to 4000 years before) of Osaka City, Japan, was previously identified as $B$. acutrostrata. Here, we revise it as above based on the alisphenoid and rostrum morphology. The specimen adds a chronologically and geographically new record to the not well-known species as that the modern distribution probably had already established about 8800 to 4000 years ago, which was the age of the Jomon transgression creating the Kawachi Bay.

\section{ACKNOWLEDGEMENTS}

We thank C. Cho (Osaka City Cultural Properties Association), T. Nakajo, and $\mathrm{Y}$, Ishii (OMNH) for discussion on geology; $\mathrm{M}$. Tsukagoshi (OMMH) for discussion on paleontology and helping with the handling of the specimen; S. Ishida $(\mathrm{OMNH})$ for an identification on the remains of invertebrates. We thank to referees, T.A. Deméré (San Diego Natural History Museum), T.K. Yamada, and C.-H. Tsai (both NSMT). Thanks go to T.K. Yamada (NSMT) for giving information about the research history of Balaenoptera omurai, B. edeni and B. brydei, and M. Oishi (Iwate Prefectural Museum, Tohoku University Museum) for discussion about referred materials. We thank to M. Ohara and Y. Kaji (both WMNH), Y. Tajima, and T.K. Yamada (both NSMT) and T. Wada $(\mathrm{OMNH})$ for their permission to examine comparative materials.

\section{REFERENCES}

Brisson, A. 1762. Regnum Animale in Classes IX distributum sive synopsis methodica. Edito altero auctior. Theodorum Haak, Leiden.

Buckley, M., Fraser, S., Herman, J., Melton, N., Mulville, J., and Pálsdóttir, A. 2014. Species identification of archaeological marine mammals using collagen fingerprinting. Journal of Archaeological Science, 41:631-641.

Buckley, M., Harvey, V.L., and Chamberlain, A.T. 2017. Species identification and decay assessment of Late Pleistocene fragmentary vertebrate remains from Pin Hole Cave (Creswell Crags, UK) using collagen fingerprinting. Boreas:1-10.

Buono, M.R., Fernández, M.S., Fordyce, R.E., and Reidenberg, J.S. 2015. Anatomy of nasal complex in the southern right whale, Eubalaena australis (Cetacea, Mysticeti). Journal of Anatomy, 226:81-92.

Cho, C. 2003. Development of the Osaka Plain and human remains, Japan Association for Quaternary Research reference. Japan Association for Quaternary Research, 1-16.

Deméré, T.A., Berta, A., and McGowen, M.R. 2005. The taxonomic and evolutionary history of fossil and mod- 
ern balaenopteroid mysticetes. Journal of Mammalian Evolution, 12:99-143.

Endo, K., Kosugi, M., Matsushita, M., Naomichi, M., Hishida, R., and Takano, T. 1989. Holocene environmental history in and around the Paleo-Nagareyama Bay, central Kanto Plain. The Quaternary Research (Daiyonki-Kenkyu), 28:61-77. (In Japanese with English abstract)

Fordyce, R.E. and de Muizon, C. 2001. Evolutionary history of whales: a review, p. 169-234. In Mazin, J.-M. and de Buffrenil, V. (eds.), Secondary Adaptation of Tetrapods to Life in Water. Pfeil, München, Germany.

Geisler, J.H. and Luo, Z. 1996. The petrosal and inner ear of Herpetocetus sp.(Mammalia: Cetacea) and their implications for the phylogeny and hearing of archaic mysticetes. Journal of Paleontology, 70:1045-1066.

Junge, G.C.A. 1950. On a specimen of the rare fin whale, Balaenoptera edeni Anderson stranded on Pulu Sugi near Singapore. Zoologische Verhandelingen 9, 126.

Kajiyama H. and Itihara M. 1972. The developmental history of the Osaka Plain with references to the radiocarbon dates. Memoirs of the Geological Society of Japan, 7:101-112. (In Japanese)

Kasuya, T. 1973. Systematic consideration of recent toothed whales based on the morphology of tympano-periotic bone. Scientific Reports of the Whales Research Institute, Tokyo, 25:1-103.

Kato, H., Shinohara, E., Kishiro, T., and Noji, S. 1996. Distribution of Bryde's whales off Kochi, southwest Japan, from the 1994/95 sighting survey. ReportInternational Whaling Commission, 46:429-436.

Kobayashi, K. 2008. Jomonjidai no rekinendai. p. 257269. In Kosugi, Y., Taniguchi, Y., Nishida, Y., and K. Yano, K. (eds.), Rekishi no monosashi: Jomon jidai kenkyu no hennen taikei. (In Japanese)

Marx, F.G., Lambert, O., and Uhen, M.D. 2016. Morphology, p. 44-94, In Marx, F.G., Lambert, O., and Uhen, M.D. (eds.). Cetacean Paleobiology. Wiley-Blackwell.

McGowen, M.R., Spaulding, M., and Gatesy, J. 2009. Divergence date estimation and a comprehensive molecular tree of extant cetaceans. Molecular Phylogenetics and Evolution, 53:891-906.

Mead, J.G. and Fordyce, R.E. 2009. The therian skull: a lexicon with emphasis on the odontocetes. Smithsonian Contributions to Zoology, 627:1-248.

Mitamura, M., and Hashimoto, M. 2004. Spatial distribution with the drilling database on the basal gravel bed of the Namba formation in the Osaka plain, south- west Japan. The Quaternary Research (DaiyonkiKenkyu), 43:253-264.

Muller, J. 1954. Observations on the orbital region of the skull of the Mystacoceti. Zoologische Mededelingen, 32:279-290.

Nishiwaki, M. 1965. Cetaceans and Pinnipeds. Tokyo University Press, Tokyo.

Ogino, T. 1998. Mysticeti fossils from the Osaka Plain of the alluvium. Unpublished graduation thesis, Shimane University, Science Division, Japan. (In Japanese)

Oishi, M. 1999. Comparison of the cranial elements around the subtemporal fossae of balaenopterid whales. Japan Cetology, 9:41-48.

Oishi, M., Wada, S., Yamada, T.K., and Imahara, Y. 2009. Re-examination of balaenopterid whales from Wakayama and Oita prefectures, Japan. Japan Cetology, 19:1-8. (In Japanese with English abstract)

Okazaki, Y. 1975. Discovery of sperm whale bones in Higashi Osaka City. Nature Study, 21:143-144. (In Japanese)

Omura, H. 1976. A skull of the minke whale dug out from Osaka. Scientific Reports of the Whales Research Institute, 28:69-72.

Osaka City Cultural Properties Association 2008. Osaka iseki. Sogensha.

Rice, D.W. 1998. Marine Mammals of the World: Systematics and Distribution. Special publication 4, Society for Marine Mammalogy, Lawrence, Kansas.

Sasaki, T., Nikaido, M., Wada, S., Yamada, T.K., Cao, Y., Hasegawa, M., and Okada, N. 2006. Balaenoptera omurai is a newly discovered baleen whale that represents an ancient evolutionary lineage. Molecular Phylogenetics and Evolution, 41:40-52.

Shindo, N. 1975. History of Whales in the Inland Sea = Histoire des Baleines de la Mer Intérieure. Hyogo Dietists' Institute, Hyogo, Japan.

Tanabe, S., Nakashima, R., Uchida, M., and Shibata, Y. 2012. Depositional process of an estuary mouth shoal identified in the alluvium of the Tokyo Lowland along the Tokyo Bay, central Japan. Journal of Geological Society of Japan (Chishitsugakuzassi), 118:119. (In Japanese with English abstract)

Taruno, H. 1984. A fossil discovery from the first construction of Midosuji subway line. Nature Study, 30:62-63. (In Japanese)

Wada, S., Oishi, M., and Yamada, T.K. 2003. A newly discovered species of living baleen whale. Nature, 426:278-281. 